\title{
JOHN J. BIGSBY, M.D., F.R.S., F.G.S., F.R.G.S.
}

Born Aug. 14th, 1792 ; Died Feb. 10th, 1881.

Dr. J. J. Bigser was the son of J. Bigsby, Esq., M.D., Edinburgh. He was born at Nottingham, on the 14th August, 1792, and early followed the career of his father by entering the Medical Profession, and shortly after taking his degree, he was appointed about 1818 as Medical Officer to a German Rifle Regiment in the English Service and ordered to Canada. Soon after his arrival he was sent by the Governor to Hawkesbury Settlement, where there had been an outbreak of typhus fever. In the following year the more agreeable task was assigned to him of travelling through Upper Canada to report upon its Geology. A part of the collections be then made are still preserved in the British Museum, not the least interesting of which are the curious siphuncles of Huronia Bigsbyi, from Drummond's Island, Lake Huron. About the year 1822 he was appointed British Secretary and Medical Officer to the Canadian Boundary Commission. In 1823 he was elected a Fellow of the Geological Society of London, to whose Transactions he had already been a contributor.

Dr. Bigsby returned to England about 1827, and commenced to practise as a medical man at Newark. In 1846 he came to reside in the metropolis, and from that date identified himself with most of the scientific societies in London. In 1850 he published the account of his experience of life and travel in North America, under the title of "Shoe and Canoe."

His first scientific paper appeared in Silliman's American Journal in 1820 , and he contributed altogether about twenty-seven papers to learned societies in London and elsewhere. His most important scientific work appeared in 1868 , entitled "Thesaurus Siluricus," being a list of all the fossils which occur in the Silurian formation throughout the world. $\mathrm{He}_{e}$ was elected a Fellow of the Royal Society in the following year, and was awarded the Murchison Medal in 1874 by the Council of the Geological Society.

In 1878 he published bis second catalogue, entitled "Thesaurus Devonico-Carboniferus," and at the time of bis death had far advanced towards the completion of his third volume, the "Thesaurus Permianus."

In 1876 he requested the Geological Society to accept, in trust, a sum of money to provide a medal to be called the "Bigsby Medal," and to be awarded biennially to some geologist not more than forty-five years of age of any nationality; Prof. Marsh, Prof. Cope, and Dr. Barrois having been up to this time the three recipients. Dr. Bigsby died at his residence, 89, Gloucester Place, Portman Square, at the good old age of 89 years.

\section{PROFESSOR JAMES TENNANT, F.G.S., F.C.S.,}

Born 1808; Died FerRuary 23Rd, 1881.

Doning the earlier part of the present century the science of Mineralogy had no more claim to be considered one of the exact sciences than has Geology at the present day. To be able to 
identify minerals "at sight," and to test them by their hardness, lustre, form, and weight, represented the common extent of a collector's acquirements. But few understood the use of a goniometer, and not many could use the blowpipe, or correctly make an analysis of a mineral in this country. It was young James Tennant's lot to come to London at an early age, and enter the service of Mr. Mawe, the well-known Mineralogist, whose shop was a centre of resort for men of science. The stock-in-trade consisted of shells, minerals, marbles, etc., most of which Mr. Mawe obtained during his frequent travels. Here Tennant gained his first acquaintance with minerals. The classes of the Mechanics' Institution which he joined, and attendance on Faraday's lectures at the Royal Institution, improved his education, and enlarged his scientific knowledge of the specimens in which his master dealt. At Mr. Mawe's death, the management of the business devolved upon Tennant, who shortly after succeeded to it as proprietor.

He derived much advantage from the friendship of Sir Everard Home, whose knowledge of crystals enabled him to impart much valuable information to Tennant.

When King's College opened in the Strand, the Council desired a teacher in Mineralogy, and applied to Faraday for his nomination of a fit person; his recommendation was in favour of Mr. Tennant, who shortly after his appointment received the title of "Professor of Mineralogy." The new position opened a wider field of usefulness and of interesting study. His after-life was devoted to the diffusion of knowledge relating to mineralogy and geology, and many of the students who attended his lectures proved that he had not taught in vain by turning out to be useful collectors and observers of minerals abroad. He was one of the strong promoters and believers in the discoveries of Diamonds in South Africa, at a time when other's denied their genuineness.

Professor 'Tennant was a very ardent advocate of technical education, and having seen the valuable application of the lathe in cutting both diamonds and other valuable stones and marbles, he induced the Turners' Company to promote the advancement of turning, by offering prizes annually for specimens in all branches of the turner's art. Great credit is due to Prof. Tennant for the revival of this branch of technical education as applied to ornamental work of all kinds and materials.

He was one of the founders of the Geologists' Association, of which body he was formerly President. He was also for several years a member of the Council of the Geological Society of London.

\section{SIR PHILIP DE MALPAS GREY-EGERTON, BART,, M.P., F.R.S., F.G.S., OF OULTON PARK, TARPORLEY, CHESHIRE.}

Born Nov. 13тh, 1806; Dird April 5th, 1881.

Another distinguished name has been erased by death from the list of Fellows of the Geological Society. Sir Philip Egerton wras the eldest son of the Rev. Sir Philip Grey-Egerton, by his wife Rebecca, youngest daughter of the late Josias Dupré, Esq., of Wilton 